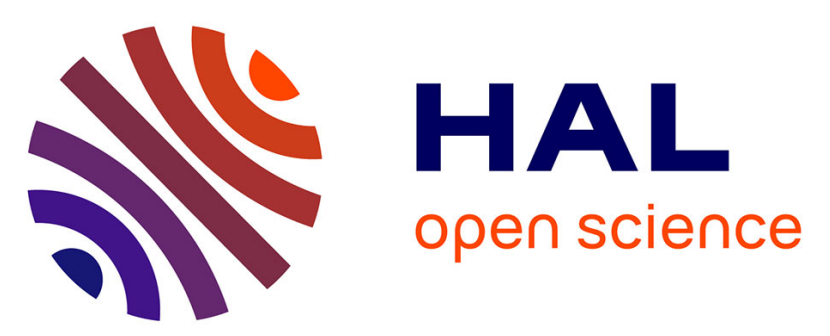

\title{
Hybrid Interfaces Made of Nanotubes and Backbone-Altered Dipeptides Tune Neuronal Network Architecture
}

Bhimareddy Dinesh, Manuela Medelin, Denis Scaini, Federica Lareno Faccini, Federica Quici, Laura Ballerini, Alberto Bianco

\section{To cite this version:}

Bhimareddy Dinesh, Manuela Medelin, Denis Scaini, Federica Lareno Faccini, Federica Quici, et al.. Hybrid Interfaces Made of Nanotubes and Backbone-Altered Dipeptides Tune Neuronal Network Architecture. ACS Chemical Neuroscience, 2020, 11 (2), pp.162-172. 10.1021/acschemneuro.9b00522 . hal-02979054

\section{HAL Id: hal-02979054 \\ https://hal.science/hal-02979054}

Submitted on 26 Oct 2020

HAL is a multi-disciplinary open access archive for the deposit and dissemination of scientific research documents, whether they are published or not. The documents may come from teaching and research institutions in France or abroad, or from public or private research centers.
L'archive ouverte pluridisciplinaire HAL, est destinée au dépôt et à la diffusion de documents scientifiques de niveau recherche, publiés ou non, émanant des établissements d'enseignement et de recherche français ou étrangers, des laboratoires publics ou privés. 


\section{Hybrid interfaces made of nanotubes and backbone-altered dipeptides tune neuronal network architecture}

Bhimareddy Dinesh ${ }^{\mathrm{a} \dagger}$, Manuela Medelin ${ }^{\mathrm{b}, \mathrm{c} \dagger}$, Denis Scaini ${ }^{\mathrm{c}, \mathrm{d}}$, Federica Lareno Faccini ${ }^{\mathrm{c}}$, Federica Quicic ${ }^{\mathrm{c}}$ Laura Ballerini ${ }^{\mathrm{c}^{*}} \&$ Alberto Bianco ${ }^{\mathrm{a}^{*}}$

${ }^{a}$ CNRS, Immunology, Immunopathology and Therapeutic Chemistry, UPR 3572, University of Strasbourg, 67000 Strasbourg, France.

${ }^{\mathrm{b}}$ Department of Life Sciences, University of Trieste, 34127 Trieste, Italy.

${ }^{c}$ International School for Advanced Studies (SISSA/ISAS), 34136 Trieste, Italy.

${ }^{\text {d }}$ ELETTRA Sincrotrone Trieste S.c.p.A., 34149 Trieste, Italy.

\section{Keywords}

Diphenylalanine, peptides, carbon nanotubes, self-assembly, hippocampal neurons, patch-clamp. 


\begin{abstract}
Peptides constituted of backbone homologated $\alpha$-amino acids combined with carbon materials offer interesting possibilities in the modulation of cellular functions. In this work we have prepared diphenylalanine $\beta$ - and $\gamma$-peptides and conjugated them to carbon nanotubes (CNTs). These hybrids were capable to self-assemble into fibrillar dendritic structures enabling the growth of primary hippocampal cells and the modulation of their neuronal functions. In particular, following the deposition of the different nanomaterials on glass substrates, we have evaluated their effects on circuit function and geometry. The geometrical restrictions due to CNT nucleated nodes allowed growing neuronal networks with control over network geometry, and exploring its functional impact. In applications diverse from basic neuroscience, the presence of CNT nodes may be exploited in brain interfaces able to convey highly localized electrical stimuli.
\end{abstract}




\section{Introduction}

Molecular self-assembly is the spontaneous association of molecules into highly ordered structures under thermodynamic and kinetic conditions. This process is ubiquitously present in Nature and it can give inspiration to design artificial supramolecular systems for application in biology and nanotechnology. ${ }^{1}$ Among the different biomolecules, peptides have gained great attention thanks to their excellent biocompatibility and functional diversity making them potential biological building blocks for the creation of biomimetic nanomaterials characterized by highly ordered and stable architectures. ${ }^{2}$

The research advances on Alzheimer's disease, which is a fatal neurodegenerative disease, have revealed the abnormal folding and rapid aggregation of amyloid- $\beta$ (A $\beta$ ) peptides as the main cause. ${ }^{3,4}$ In efforts to identify motifs of aggregation, diphenylalanine (FF), the core recognition motif of $\mathrm{A} \beta$, is the most studied ultrashort peptide forming amyloid kind of fibers in terms of self-assembly. Moreover, the combination of $\mathrm{F} / \mathrm{FF}$ and other aromatic/aliphatic amino acid residues have been explored as alternative systems to understand the role of F/FF in the formation of amyloid fibers. ${ }^{5-9}$ The diversity of nanostructures such as nanotubes, ${ }^{10}$ nanofibers, ${ }^{11}$ nanovesicles ${ }^{12}$ and nanowires ${ }^{13}$ that are obtained by simple modifications to this basic unit, hints at the possibility to explore a wide range of applications. In addition, the amino acid residues with alterations on the backbone or the side chains are of new interest to generate secondary structural motifs in peptidomimetics. ${ }^{14,15}$ The peptides containing such modified monomer units display enhanced biological stability. ${ }^{16,17}$ In this context, the exploitation of the backbone of the FF in combination with inorganic nanomaterials, leading to spatially well-organized hybrid structures, may open new opportunities in nanoscience. ${ }^{18}$ To this end, we recently showed the capacity of selfassembled nanofibers, made of backbone modified FF, to form regular dendritic 
structures when covalently conjugated to carbon nanotubes (CNTs). ${ }^{19}$ Having in mind the potentials of CNTs as neuronal interfaces, as demonstrated over the last two decades both in vitro and in vivo, ${ }^{20-27}$ the intrinsic dendritic structures of backbone modified FFCNT conjugates led us to explore their potential as substrate to enhance neuronal growth and modulate neuronal functions. ${ }^{19}$

Neurons, as many cell types, need to be attached to a substrate in order to survive, grow and build multiple tissue architectures. In vivo, neuronal cell phenotypes are in direct contact with the extracellular matrix (ECM), a complex mixture of proteins (such as laminin, collagen, fibronectin and glycoproteins) and other macromolecules. ECM composition and structure plays a central role cell differentiation, neuronal cell development and circuit formation. ${ }^{28}$ Several studies proposed synthetic ECM mixtures to enhance or control neuronal adhesion and growth on the surface of nanomaterials, of particular interest emerged the possibility to artificially direct the spatial distribution of neurons ${ }^{29}$ or to guide axonal growth. ${ }^{30}$ In the spatial control of neurons and axons, topographical features of growth substrates may play also an important role, even in the absence of adhesion proteins. ${ }^{31}$ Geometrical features at the micro/nano-scale $p e r s e^{32}$ can, in fact, instruct neuronal morphology or network wiring. Investigating new approaches toward bioengineering neuronal growth platforms may represent an important advance when, for example, studying electrical activity within controlled neuron geometry or interfacing neuronal circuits with engineered microelectronics, are desired. In vitro standard neuronal networks usually lack geometrically defined features, due to the random spatial distribution of cells. Here, we present a study on the capability of the backbone-homologated analogues of diphenylalanine motif constituted of $\beta^{3} \mathrm{Phe}$ and $\gamma^{4} \mathrm{Phe}$ as new neuronal growth interfaces when conjugated to CNTs. The $\beta^{3}$ Phe and $\gamma^{4}$ Phe amino acids were derived by homologation of the naturally occurring $\alpha \mathrm{Phe}$, and used to synthesize the relative dipeptides (from now on, $\beta$ peptide and $\gamma$ peptide). The CNT hybrids and the $\beta$ and $\gamma$ peptide precursors were deposited on 
glass substrates to allow the growth of primary hippocampal cells. The effects of the different nanomaterials on circuit function and geometry were evaluated.

\section{Results}

\subsection{Preparation and characterization of CNT-peptide nanomaterials}

Aiming to understand the role of carbon nanotubes conjugated with $\beta$ and $\gamma$ homologated peptides on growth of neuronal cells, we initially prepared the N-Bocprotected $\beta$ and $\gamma$ diphenylalanines corresponding to Boc- $\beta^{3}(\mathrm{R}) \mathrm{Phe}-\beta^{3}(\mathrm{R}) \mathrm{Phe}-\mathrm{OH}(\beta-$ peptide) and Boc- $\gamma^{4}(\mathrm{R}) \mathrm{Phe}-\gamma^{4}(\mathrm{R}) \mathrm{Phe}-\mathrm{OH}\left(\gamma\right.$-peptide), respectively (Figure 1, left). ${ }^{19}$ The peptides were subsequently linked to the carboxylic functions of oxidized multiwalled carbon nanotubes via a diaminotriethylene glycol spacer (Figure 1, right). ${ }^{19}$ The ability of $\beta$ and $\gamma$ peptides and the corresponding CNT-peptide conjugates (CNT- $\beta$ and CNT- $\gamma$ peptides, respectively) to form different dendritic structures when plated on glass substrates was already demonstrated. ${ }^{19}$ Herein, we deposited the peptides on flat borosilicate glass coverslips, commonly used for electrophysiology experiments (see Methods), and characterized the resulting films by means of scanning electron microscopy (SEM) investigation (Figure 2). As previously shown, the $\beta$ peptide forms large tangles of fibers originating from a central nucleating point partially covered by a lamina-like hat (Figure 2a, top), while the film generated by the $\gamma$ peptide nanofibers, shorter and more compact than $\beta$ ones, appears more uniform and thinner (Figure 2a, bottom). This peptide arrangement is very similar to our previous results. ${ }^{19}$ Although both peptides give rise when conjugated with CNTs to star-like dendritic assemblies with CNTs presumably staying at the core of the formation, ${ }^{19}$ such structures occurred at a lower density and appear smaller in the case of $\gamma$ peptide than $\beta$ peptide (Figure $2 b$ ). Apparently in accordance with the organization described previously, ${ }^{19}$ where the 
dimensions of the nucleation points of the dendritic structures were smaller in $\gamma$-peptide conjugated to CNTs. Regardless the diverse topographical features of the two peptides at the microscale, both compositions covered evenly the supporting glass substrates resulting in a continuous film.

\subsection{Interfacing CNT- $\beta$ peptide-coated substrates to neuronal network: effects on circuit function and morphology}

Diphenylalanine peptide is one of the most studied building blocks for possible application in the biomedical field ${ }^{33}$ however, its homologated analogues $\beta$ Phe and $\gamma \mathrm{Phe}$, their functionalization with CNTs and their biocompatibility with neuronal cultures have never been examined before, and light open new perspectives. We explored the newly engineered substrates ability to sustain neuronal growth and synapse formation in vitro by culturing dissociated hippocampal neurons and glial cells directly in contact with the different growing platforms (poly-ornithine as control, $\beta$ peptide and CNT- $\beta$ peptide). In a first set of experiments we performed electrophysiological recordings to estimate synaptic activity and cell viability after 8 to 10 days in vitro (DIV). By single-cell patch-clamp recordings, we firstly assessed neuronal passive membrane properties, namely membrane capacitance $\left(\mathrm{C}_{\mathrm{m}}\right)$ and input membrane resistance $\left(R_{i n}\right)$ that provide an indirect measure of neuronal maturation, dimension and viability. These results are summarized in Table 1, healthy neurons grew apparently in a comparable fashion in all substrates, as indicated by the similarity of these measures. In all recorded neurons, the occurrence of spontaneous post-synaptic currents (PSCs), which appeared as heterogeneous inward deflections of variable amplitudes (Figure 3a), provided a clear evidence of functional synapse formation. ${ }^{22}$ While no differences were observed concerning PSC peak amplitude values among the three conditions (Table 2), we detected a progressive decrease in the PSCs frequency in neurons grown on $\beta$ 
peptide, such a reduction reached significance in CNT- $\beta$ peptide substrates when compared to poly-ornithine ones (Figure 3a and box plots in Figure 3b, Table 2).

By off-line analysis (see Methods) we isolated fast decaying PSCs from slow decaying PSCs, reported to be excitatory glutamate mediated currents and inhibitory GABA mediated ones, respectively. ${ }^{34}$ Fast (AMPA glutamate receptor mediated, see Methods) and slow (GABA receptor mediated, see Methods) events were characterized by a decay time constant $\tau$ equal to $2.8 \pm 0.1 \mathrm{~ms}$ and $20.7 \pm 0.9 \mathrm{~ms}$, respectively. The lower PSCs frequency trend in $\beta$ peptide substrates was apparent in both fast and slow events, even when separated (Table 2 and box plots in Figure 3b), however, only in slow PSCs such a reduction was significant, suggesting that inhibitory synapses may be the most affected, particularly when the $\beta$ peptide is associated with CNTs. To further investigate the inhibitory synaptic component, we pharmacologically isolated $\mathrm{GABA}_{\mathrm{A}}$-mediated currents (IPSCs) by blocking glutamate-mediated excitatory transmission via a simultaneous administration of CNQX (AMPA/kainate receptor antagonist) and APV (NMDA receptor antagonist; Figure 3c). In the absence of excitatory drive, i.e. in a "pure" inhibitory network, IPSCs were still significantly reduced $(\mathrm{P}=0.0051)$ by CNT$\beta$ peptide substrates as indicated by the box plots (Figure $3 \mathrm{~d}$ ), supporting a direct reduction in GABAergic activity.

Since changes in the inhibitory circuit component may affect collective network behavior, we further addressed network synaptic activity in the three growth conditions, by simultaneously measuring intracellular calcium dynamics from different neurons (see Methods). We monitor fluorescence calcium imaging by sampling from representative regions basal synaptic events and those boosted by bath-application of bicuculline (a $\mathrm{GABA}_{\mathrm{A}}$-receptor antagonist; Figure 4a, right). At the end of each recording session we added TTX (a voltage-gated sodium channel blocker) to confirm the neuronal nature of the recorded cells. ${ }^{25}$ At $>8$ DIV neurons display spontaneous basal activity including bursts emerging by irregular synchronized firing epochs. ${ }^{21,22}$ In 
our recordings, spontaneous calcium events were detected in the majority of recorded neurons before (range active cell between $62 \%$ and 75\%, Table 3 and Figure $4 \mathrm{~b}$ ) and after (range between $81 \%$ and $84 \%$, Table 3 ) the addition of bicuculline, and spontaneous occurrence of events (measured as IEI, bar plots in Figure 4c, left, and Table 3) was only slightly, but not significantly, affected by the removal of GABAergic inhibition, although the ratio between IEI values before and after bicuculline is increased in the $\beta$ peptide substrates (from 1.2 in control to 2.3 and 1.6 in $\beta$ peptide and CNT- $\beta$ peptide, see Figure $4 \mathrm{c}$, right), suggesting a slightly altered ratio between glutamate-mediated and GABA-mediated transmission in $\beta$ peptide circuits. ${ }^{25}$

The detected changes in activity profile from single cell recordings and from collective live imaging hint at subtle changes in network composition or topology brought about by $\beta$ peptide surfaces, in the absence of clear indication of altered neuronal viability. We used immunofluorescence techniques and fluorescence microscopy to compare cultures grown on the different substrates. We imaged by immunofluorescence the specific cytoskeletal components $\beta$-tubulin III, to visualize neurons, and glial fibrillary acidic protein (GFAP) to visualize astrocytes, nuclei were counterstained with DAPI (Figure 5a). Bar plots in Figure 5b and Table 4 quantify neuronal and glial densities (top and bottom, respectively) and fluorescent-positive area for both neurons and astrocytes (Figure 5c, left and right, respectively). Surprisingly, in $\beta$ peptide and CNT$\beta$ peptide growth platforms, despite the clear reduction in synaptic activity, we detected an increased neuronal density associated with higher $\beta$-tubulin III-positive area, suggestive of an improved adhesion/survival of neuronal phenotypes accompanied by an enlargement of the neuronal dendritic tree. Conversely, $\mathrm{GFAP}^{+}$glial cells were apparently increased in terms of cell density only in the CNT- $\beta$ peptide interfaces (Table 4 and Figure 5c). 
Therefore, $\beta$ peptide enriched substrates, and in particular CNT- $\beta$ peptide ones, tune synaptic activity by reducing the appearance of inward GABAergic synaptic currents. However, such a reduction had not major impacts in the collective network behavior detectable by calcium imaging. On the other hand, $\beta$ peptide substrates clearly support neuronal adhesion and growth more efficiently when compared to controls. This apparent discrepancy may be explained by a different topological organization of the neuronal circuits, due to the dendritic structure of such substrates (as shown in Figure 2 by SEM measures), leading to an altered wiring, expressed as reduction in GABAergic events at the single cell level, that does not affect significantly basal or disinhibited collective behaviors (i.e. calcium events), probably due to homeostatic network adjustments. ${ }^{35}$ We quantified the neuronal distribution in the different substrates. Figure 5d shows that the obtained Gaussian curves of neuronal cell body density distribution (see Methods) are wider for $\beta$ peptide substrates when compared to poly-ornithine, indicating a discontinuous spatial distribution in $\beta$ peptide substrates characterized by highly populated areas alternated to others with mainly neuronal fibers. The width of the Gaussians is determined by the standard deviations $(\sigma)$ that were comparable between $\beta$ peptide and CNT- $\beta$ peptide $(16.68 \pm 0.93, \mathrm{n}=16$ and 15.16 $\pm 1.13, \mathrm{n}=14$, respectively; $\mathrm{n}=$ number of coverslips; $\mathrm{P}=0.47$ ) but both nanomaterials were statistically different from poly-ornithine $(7.06 \pm 0.49, \mathrm{n}=11 ; \mathrm{n}=$ number of coverslips; $\mathrm{P}<0.01)$. Our results suggest that the structure of $\beta$ peptide substrates instructed the geometry of hippocampal circuits by favoring the formation of neuronal clusters and improving neuronal dendritic ramification. Such changes might be responsible of a diverse synaptic organization.

\subsection{Interfacing CNT- $\gamma$ peptide-coated substrates to neuronal network: effects on}

\section{function and morphology}


A broader question is to what extent the topology of CNT- $\beta$ peptide and $\beta$ peptide substrates is instrumental in modifying the circuit construction. To address this issue we investigated another homologated peptide. The $\gamma$ peptide differs from the $\beta$ peptide structure by an additional degree of flexibility introduced by the second methylene group in the peptide backbone (see Figure 1). As previously shown, the $\beta$ peptide allows to form nanofiber bundles originating from a central nucleating point, while the nanofibers generated by the $\gamma$ peptide are shorter, more compact and, more importantly, aligned in parallel-like arrangement creating a sort of film. ${ }^{19}$ On the other hand, although both peptides when co-assembled with CNTs give rise to regular dendritic assemblies with CNTs present at the core of the ramifications likely nucleating their formation, ${ }^{19}$ such structures were less represented in the case of $\gamma$ peptide. In fact, $\gamma$ peptide, although able to create a uniform film above the supporting glass slide, gives rise to more flatten films than $\beta$ peptide (Figure $2 \mathrm{a}$ ). A similar behavior is observable in the case of CNT- $\gamma$ peptide too (Figure 2b). In the latter case, anyhow, small fibril nucleation points are present at a density comparable to CNT- $\beta$ peptide samples.

Therefore, we decided to investigate how different structured substrates impact on neuronal network morphology and, as a result, how these changes affect the synaptic activity. Similar to $\beta$ peptide substrates, when hippocampal neurons were cultured for $>8$ DIV on $\gamma$ peptide and CNT- $\gamma$ peptide growth platforms neuronal and glial cell densities were increased in CNT- $\gamma$ peptide substrates, accompanied by increases in the $\beta$-tubulin III area, with no changes in GFAP one (summarized in Figure 6a, b and c, Table 5) supporting the notion that, in particular when nucleated by CNT, CNT- $\gamma$ peptide are favorable substrates for hippocampal cells adhesion, growth and survival.

In Figure $6 \mathrm{~d}$ the analysis of the neuronal cell body distribution is shown. The measured Gaussian curve of neuronal density distribution was larger in CNT- $\gamma$ peptide $(\sigma=14.58$ $\pm 1.37, \mathrm{n}=12 ; \mathrm{n}=$ number of coverslips) when compared to the other two conditions 
$(\sigma=11.89 \pm 1.98, \mathrm{n}=10$ and $\sigma=11.21 \pm 1.23, \mathrm{n}=11$ for poly-ornithine and $\gamma$ peptide respectively; $\mathrm{n}=$ number of coverslips), even though not reaching a significant statistical difference (Poly-ornithine vs. $\gamma$ peptide $\mathrm{P}=0.95$, vs. $\mathrm{CNT}-\gamma$ peptide $\mathrm{P}=0.44$; $\gamma$ peptide vs. CNT- $\gamma$ peptide $\mathrm{P}=0.26$ ). Thus, apparently, such substrates were less effective in governing neuronal clusterization. Accordingly, when comparing the electrophysiological recordings (where we detected no differences in passive membrane properties, Table 6), spontaneous PSCs peak amplitude and frequency were not affected by the different substrates (Table 7 and Figure 7).

\section{Discussion}

In developing novel therapeutic tools in biomedicine, such as interfaces, prostheses, or bio-devices, the design of novel composite biomaterials is a crucial aspect. In recent years, research on peptide-based materials has experienced remarkable interest, including studies investigating the nanometric and mesoscopic structures from basic peptide motifs and their potential applications in tissue engineering or cell adhesion. Natural components, such as peptides, are definitely interesting due to their inherent biodegradability, biocompatibility, and critical biological functions. Moreover, the possibility of further implementing biopolymers with inorganic materials, such as CNTs, will lead to the generation of hybrid nanomaterials endowed with multifunctional activities. ${ }^{36}$ In the present work, we investigated novel self-assembling peptides ( $\beta$ and $\gamma$ peptides) and the same peptides conjugated with CNTs, as possible neural interfaces able to shape network morphology and activity. Importantly, the low amount of CNTs on the surface precludes these materials from exerting the previously documented boosting effect on network activity. ${ }^{20-23}$ Thus CNTs seem to act as supporting material for the nucleation of peptide star-like aggregations around them. This could give rise to a local increase in the amount of peptide and, thanks to CNTs 
ability to interact with the cell membrane, ${ }^{21,37}$ may facilitate the interaction of the peptide with the cells.

We discovered that hippocampal neurons adhesion and growth were favored by both peptide-based substrates tested, in particular when coupled to CNTs. Our peptides promote neuronal survival even when used alone. This effect is enhanced when peptides are combined with CNTs. In this configuration, moreover, an increase in glial densities is observed too. These findings, together with the preserved membrane passive properties, highlight the substantial biocompatibility of such composites. Surprisingly, $\beta$ peptide exerts an appreciable reduction in neuronal network events' frequency, although not significant, when it is used alone (Figure $3 b$ and $3 d$ ), an effect that reached significance in the case of CNT- $\beta$ peptide surface modification.

We further demonstrated that this reduction is selectively affecting slow/GABAergic events (IPSCs; Figure $3 b$ and d). In our recording conditions, chloride mediated synaptic events are detected as inward currents. ${ }^{20,22,37} \mathrm{~A}$ shift in the intracellular chloride concentration, brought about by CNT- $\beta$ peptide, may be responsible for an altered neuronal maturation and improved chloride extrusion, ${ }^{38,39}$ generating a shift in $\mathrm{Cl}^{-}$reversal potential potentially hindering the detection of GABAergic events. Our recording conditions do not allow confirming a real change in the internal chloride concentration. Although the slightly stronger inhibitory control of calcium events is supportive of this hypothesis, it is difficult to explain why CNT- $\gamma$ peptide and $\gamma$ peptide are, instead, not able to improve this hypothetical maturation of the circuit.

To understand the reason for the observed difference in PSCs, we examined an additional primary variable that changes with the different substrates: the ability to generate dendritic-like structures. Indeed, such structures are well described in $\beta$ peptide and up-regulated in CNT- $\beta$ peptide and could guide neuronal circuits topologies, leading to re-organized synaptic interactions. ${ }^{40}$ In agreement with this hypothesis, we detected a different neuronal distribution in $\beta$ peptide platforms, 
enhanced by CNT hybrids. Moreover, in the case of $\gamma$ peptide, with or without the CNT, the limited presence of similar structures is in accordance with the absence of synaptic changes. Thus, CNT- $\beta$ peptide and $\beta$ peptide may instruct the formation of a network artificially enriched of more "hubs", active neuronal clusters.

The exact mechanism involved in the peptide/cell and peptide/CNT/cell interactions is not well understood, and it is the objective of further investigation. Importantly, the difference between $\beta$ - and $\gamma$-peptide behavior is to be found, presumably, in the different structures the two peptides have.

\section{Conclusions}

Integrating CNTs to different peptides allows the self-assembly of nanostructures characterized by diverse organization. These dendritic organizations were challenged as neuronal growth substrates and we describe that, the emerging topology of the dendritic structures, ultimately more relevant than the peptide and CNTs per se, may be reflected into the morphology and function of the interfaced neuronal circuits. In this work, we highlighted the combined effect that CNTs and peptides have in modulating neuronal electrical activity. This effect is new being different from the boosting effect induced by CNT carpets. $^{20-23}$ It opens to the use of this new CNT/peptide hybrid complex as a neuromodulating agent, possessing cell survival ability, to specifically interact with GABAergic neurons. Importantly, even though our study dealt with flat surfaces, the same approach could be applied to cover the surfaces of every threedimensional scaffold, such a feature might be of interest in future tissue engineering and neuronal interfacing applications. 


\section{Experimental Section}

\subsection{Materials}

All reagents were obtained from commercial suppliers and used without further purification. Purified multi-walled carbon nanotubes (MWCNT) were purchased from Nanostructured \& Amorphous Materials Inc. (Houston, USA). Regular MWCNTs used in this study were $95 \%$ pure, stock No. $1240 \mathrm{XH}$. Outer average diameter was between 20 and $30 \mathrm{~nm}$, and length between 0.5 and $2 \mu \mathrm{m}$ before oxidative treatment. The synthesis and the characterization of the different CNT-peptide conjugates were performed following the protocols and the techniques described in our previous work. ${ }^{19}$ Briefly, MWCNTs were initially oxidized and the $\mathrm{COOH}$ groups were functionalized with a diaminotriethylene glycol (TEG) chain. The terminal amino function of TEG was coupled to the $C$-terminus of the Boc-protected $\beta$ - and $\gamma$-peptides (Figure 1). The Boc group was finally removed using $\mathrm{HCl}$ in dioxane. After neutralization, the amount of peptide covalently linked to the nanotubes was calculated by thermogravimetric analysis and corresponded to 126 and $84 \mu \mathrm{mol} / \mathrm{g}$ for the CNT- $\beta$ peptide and CNT- $\gamma$ peptide, respectively. ${ }^{19}$ The peptide and the CNT-peptide substrates were prepared by a spraying coating procedure. Briefly, an air brush (HP-SB, Iwata, Japan) was used to nebulize the diphenylalanine peptides alone and the CNT-peptides mixed with the diphenylalanine peptides (1:5 ratio) (all at $50 \mu \mathrm{g} / \mathrm{mL}$ concentration in ethanol) on glass coverslips $\left(12 \times 24 \mathrm{~mm}^{2}, 0.13 \div 0.16 \mathrm{~mm}\right.$ in thickness, Kindler, EU). Glass coverslips were positioned on a hot plate maintained at $40{ }^{\circ} \mathrm{C}$ to induce the immediate evaporation of the solvent (ethanol) and deposition of a uniform, thin, layer of material. Several steps of nebulization were performed in order to deposit a final quantity of $100 \mu \mathrm{L}$ on each coverslip. 


\subsection{Cell culture}

Primary cultures of hippocampal neurons were obtained from 2 or 3 days postnatal (P2P3) rat pups as previously reported. ${ }^{20-22,25}$ Briefly, hippocampi were isolated and cells were dissociated enzymatically and mechanically. Cells were plated $(150 \mu \mathrm{L}$ of cell suspension) on glass coverslips $\left(12 \times 24 \mathrm{~mm}^{2}, 0.13 \div 0.16 \mathrm{~mm}\right.$ in thickness, Kindler, EU) coated with poly-L-ornithine (as control), $\beta$ peptide alone, $\gamma$ peptide alone and both peptides combined with CNTs (CNT- $\beta$ peptide and CNT- $\gamma$ peptide, respectively). Cultures were incubated in culture medium at $37^{\circ} \mathrm{C}$, in a humidified atmosphere with 5\% $\mathrm{CO}_{2}$. Minimum essential medium (MEM; from Gibco) containing also: $35 \mathrm{mM}$ glucose (Carlo Erba Reagents), 15 mM HEPES, 1 mM Apo-Transferrin, $48 \mu \mathrm{M}$ Insulin, $3 \mu \mathrm{M}$ Biotin, $1 \mathrm{mM}$ Vitamin B12 (all from Sigma-Aldrich) and $500 \mathrm{nM}$ Gentamicin (Gibco) in the presence of $10 \%$ dialyzed fetal bovine serum (FBS, Invitrogen). Culture medium (supplemented with cytosine-arabinoside Ara C, a proliferation inhibitor, and with a lower concentration of serum, 5\%) was renewed (60\% medium replacement) after two days from seeding and changed every two days. Cultures were then used for experiments after 8 to 10 DIV.

\subsection{Electrophysiological recordings}

For patch clamp recordings (whole-cell, voltage clamp mode performed at room temperature, RT), samples were positioned in a recording chamber, mounted on an inverted microscope and continuously superfused with a control physiological saline solution containing (mM): $150 \mathrm{NaCl}, 4 \mathrm{KCl}, 2 \mathrm{CaCl}_{2}, 1 \mathrm{MgCl}_{2}, 10 \mathrm{HEPES}$ and 10 glucose. The $\mathrm{pH}$ was adjusted to 7.4 with $\mathrm{NaOH}$ (osmolarity: 300 mOsm). Cells were patched with glass pipettes $(4 \div 7 \mathrm{M} \Omega)$ filled with a solution of the following composition (mM): $120 \mathrm{~K}$ gluconate, $20 \mathrm{KCl}, 2 \mathrm{MgCl}_{2}, 2 \mathrm{Na}_{2} \mathrm{ATP}, 10$ HEPES and 10 EGTA. pH was adjusted to 7.3 with $\mathrm{KOH}$ (osmolarity: $295 \mathrm{mOsm}$ ). Voltage values indicated in the text and in the figures have not been corrected for the liquid junction 
potential, estimated to be about $14 \mathrm{mV} .{ }^{41}$ Electrophysiological responses were amplified (EPC-7, HEKA; Multiclamp 700B, Axon Instruments), sampled and digitized at $10 \mathrm{kHz}$ within pClamp software (Axon Instruments) for offline analysis. Single spontaneous synaptic events were detected by the use of the AxoGraphX (Axograph Scientific) event detection program ${ }^{42}$ and Clampfit 10.4 version (pClamp suite, Axon Instruments). On average, $\geq 400$ events were analyzed for each cell in order to obtain mean parameters. Neuronal passive properties were measured by repeated ( 80 times) stimulation of cells with a $100 \mathrm{~ms}$ lasting hyperpolarizing stimulus $(5 \mathrm{mV})$. The areas below capacitive transients were computed and normalized for voltage transient amplitude to calculate cell capacitance $\left(\mathrm{C}_{\mathrm{m}}\right)$. Input resistance $\left(\mathrm{R}_{\mathrm{in}}\right)$ was obtained through Ohm's law, by measuring the amplitude of steady state current generated by the voltage transient. In our recording conditions, all the currents are seen as inward and can be discriminated in fast decaying (typically excitatory, glutamate-mediated) and slow decaying (typically inhibitory, GABA-mediated) events based on their different kinetic parameters. ${ }^{34}$ GABA postsynaptic currents (PSCs) were recorded in the presence of 6cyano-7-nitroquinoxaline-2,3-dione (CNQX; $10 \mu \mathrm{M}$, Sigma) and DL-2-amino-5phosphonopentanoic acid (APV; $12.5 \mu \mathrm{M}$, Sigma), blockers of AMPA/kainate subtype of glutamatergic receptors and NMDA receptors, respectively. We measured the interevent interval (IEI) considered as the time (expressed in seconds) elapsing between two consecutive onsets of current peaks and plotted by means of cumulative probability analysis.

\subsection{Calcium imaging}

For $\mathrm{Ca}^{2+}$ measurements, cultures were loaded with cell permeable $\mathrm{Ca}^{2+}$ dye Oregon Green 488 BAPTA-1 AM (Molecular Probes); stock solution of the $\mathrm{Ca}^{2+}$ dye (4 mM) was prepared in DMSO and cultures were incubated with a final concentration of $2 \mu \mathrm{M}$ for $30 \mathrm{~min}$ at $37^{\circ} \mathrm{C}$ in the cell culture incubator. Samples were then placed in a 
recording chamber mounted on an inverted microscope (Ti Eclipse, Nikon) and continuously superfused with the same control physiological saline solution used for electrophysiological experiments. A 20× objective (0.45 NA; ELWD, Nikon) was used to perform the recordings in real-time videomicroscopy. Images were continuously acquired by the HC Image software (Hamamatsu) at 6.67 frame/second (exposition time $=150 \mathrm{~ms}$ ). The $\mathrm{Ca}^{2+}$ dye was excited with a $488 \mathrm{~nm}$ wavelength light generated by a mercury lamp as light source and the fluorescent light was detected by a high-resolution CMOS camera (Orca flash 4.0, Hamamatsu). In order to induce rhythmic bursts, bicuculline methiodide $\left(\mathrm{GABA}_{\mathrm{A}}\right.$ receptor antagonist; $10 \mu \mathrm{M}$, Sigma) was bath-applied after $8 \mathrm{~min}$ of spontaneous activity recording; at the end of each experiment, tetrodotoxin (TTX, voltage-gated fast $\mathrm{Na}^{+}$channel blocker; $1 \mu \mathrm{M}$, Latoxan) was added to the recording solution to assess the neuronal nature of the recorded activity. Images sequences were analyzed off-line with the freeware ImageJ distribution Fiji, ${ }^{43}$ Clampfit 10.4 version and Igor Pro Software 6.38 version (WaveMetrics). Regions of interest (ROIs) considering neuronal soma were selected $(30 \div 50$ cells per field). Numbers of active cells over the total number of cells in the analyzed fields were evaluated. IEI considered as the time (expressed in seconds) elapsing between two consecutive onsets of intracellular calcium transients was calculated in both spontaneous activity and bicuculline conditions. Only those peaks exceeding of five times the standard deviation of the baseline noise were considered as events.

\subsection{Immunocytochemistry, image acquisition and analysis}

Immuno-labeling on dissociated hippocampal neurons was performed after fixation with 4\% formaldehyde (prepared from fresh paraformaldehyde) in PBS for $20 \mathrm{~min}$ at room temperature. Cells were permeabilized and blocked in 5\% FBS and 0.3\% Triton X-100 for at least 30 min at RT and incubated with the following primary antibodies for 30 min: rabbit polyclonal anti- $\beta$-tubulin III (Sigma-Aldrich, T2200, 1:500) and 
mouse monoclonal anti-glial fibrillary acid protein (GFAP; Sigma-Aldrich, G3893, 1:500). Upon washing, cells were then incubated for $30 \mathrm{~min}$ with the following secondary antibodies: goat anti-rabbit Alexafluor 594 (Invitrogen, A-11012, 1:500), goat anti-mouse Alexafluor 488 (Invitrogen, A-11001, 1:500) and 4, 6-diamidine-2phenylindole dihydrochloride (DAPI, Invitrogen, D1306, 1:200) for nuclei. Finally, samples were washed in PBS and quickly rinsed with Milli- $\mathrm{Q}^{\circledR}$ water to remove the PBS salt residual and mounted on glass microscope slides using Vectashield hard set mounting medium (Vector Laboratories). Fluorescence images were acquired using a Leica DM6000 upright microscope with a 20× dry objective (field size $713 \times 533 \mu \mathrm{m}^{2}$ ). Identical binning, gains and exposure times were used for all images of the same marker. Image analysis was performed using the Volocity image analysis software (PerkinElmer) and Fiji. ${ }^{43}$ For the quantification of the $\beta$-tubulin III and GFAP positive area, a threshold was set for both intensity and object size, thus ensuring that the observed signal indicates the presence of genuine positive labeling. ${ }^{26}$ Fluorescence intensity was quantified using Fiji. ${ }^{43}$ Data have then been reported as $\beta$-tubulin III and GFAP area as a percentage of the total area. Cell density counting analysis (number of cells $/ \mathrm{mm}^{2}$ ) was performed from the colocalization of DAPI and $\beta$-tubulin III signals (for neuronal density) or of DAPI and GFAP signals (for glial density). These allowed visualizing double positive cells for nuclei and $\beta$-tubulin III or GFAP, respectively. We measured at least three fields randomly selected from each sample per condition. For the network geometry analysis, we determined the neuronal density in 8 ROIs of fixed coordinates (in order to remove biased analysis) for every image acquired with a $10 \times$ dry objective. A normal distribution analysis (Gaussian curve) was performed to qualitatively appreciate the neuronal distribution and the statistical analysis was done on the standard deviation $(\sigma)$ of the neuronal density for each field. 


\subsection{Scanning electron microscopy}

Pristine peptides and CNT conjugates film morphology was investigated by means of

SEM. The as-produced substrates were imaged, after gold metallization via a metal sputter coater (Polaron SC7620), taking advantage of a Gemini SUPRA 40 SEM (Carl Zeiss GmbH, Germany). We collected secondary electrons operating at an accelerating voltage of about $5 \mathrm{keV}$.

\subsection{Statistical analysis}

Results are presented as mean \pm standard error (SE); $n$ is the number of neurons, if not otherwise indicated. One-way analysis of variance (one-way ANOVA) was used to determine significance when multiple groups were compared and Tukey's post hoc test was used to determine significance for parametric data. Kruskal-Wallis test was used for non-parametric data. $\mathrm{P}<0.05$ was accepted as indicative of a statistically significant difference.

\subsection{Ethical Statement}

All animal procedures were conducted in accordance with the National Institutes of Health, international and institutional standards for the care and use of animals in research, and after consulting with a veterinarian. All experiments were performed in accordance with the EU guidelines (2010/63/UE) and Italian law (decree 26/14) and were approved by the local authority veterinary service. All efforts were made to minimize animal suffering and to reduce the number of animals used. The Italian Ministry of Health, in agreement with the EU Recommendation 2007/526 /CE, approved animal use. 


\section{Author information}

Corresponding Authors

*E-mail: a.bianco@ibmc-cnrs.unistra.fr, laura.ballerini@ sissa.it

$\dagger$ These authors contributed equally to this work

\section{ORCID}

Denis Scaini: 0000-0001-8398-8074

Laura Ballerini: 0000-0001-8420-0787

Alberto Bianco: 0000-0002-1090-296X

\section{Acknowledgements}

We acknowledge financial support from the NEUROSCAFFOLDS-FP7-NMP-604263, PRIN-MIUR n. 2012MYESZW and the ByAxon No. 737116 to L.B. This work was also supported by the Centre National de la Recherche Scientifique (CNRS), by the Agence Nationale de la Recherche (ANR) through the LabEx project Chemistry of Complex Systems (ANR-10-LABX-0026_CSC), and by the International Center for Frontier Research in Chemistry (icFRC).

\section{References}

(1) Huang, R.; Wang, Y.; Qi, W.; Su, R.; He, Z. Temperature-Induced Reversible Self-Assembly of Diphenylalanine Peptide and the Structural Transition from Organogel to Crystalline Nanowires. Nanoscale Res. Lett. 2014, 9 (1), 653.

(2) Yan, X.; Zhu, P.; Li, J. Self-Assembly and Application of Diphenylalanine-Based Nanostructures. Chem. Soc. Rev. 2010, 39 (6), 1877-1890.

(3) Mondal, P.; Khan, J.; Gupta, V.; Ghosh, S. In Silico Approach for Designing Potent Neuroprotective Hexapeptide. ACS Chem. Neurosci. 2019, 10 (6), 3018-3030.

(4) Mondal, P.; Das, G.; Khan, J.; Pradhan, K.; Mallesh, R.; Saha, A.; Jana, B.; Ghosh, S. Potential Neuroprotective Peptide Emerged from Dual Neurotherapeutic Targets: A Fusion Approach for the Development of Anti-Alzheimer's Lead. ACS Chem. Neurosci. 2019, 10 (5), 2609-2620.

(5) Tao, K.; Levin, A.; Adler-Abramovich, L.; Gazit, E. Fmoc-Modified Amino Acids and Short Peptides: Simple Bio-Inspired Building Blocks for the Fabrication of Functional Materials. Chem. Soc. Rev. 2016, 45 (14), 3935-3953.

(6) Fleming, S.; Ulijn, R. V. Design of Nanostructures Based on Aromatic Peptide Amphiphiles. Chem. Soc. Rev. 2014, 43 (23), 8150-8177. 
(7) Kaur, G.; Abramovich, L. A.; Gazit, E.; Verma, S. Ultrastructure of Metallopeptide-Based Soft Spherical Morphologies. RSC Adv. 2014, 4 (110), 6445764465.

(8) Maity, S.; Nir, S.; Reches, M. Co-Assembly of Aromatic Dipeptides into Spherical Structures That Are Similar in Morphology to Red and White Blood Cells. J. Mater. Chem. B. 2014, 2 (17), 2583-2591.

(9) Adler-Abramovich, L.; Vaks, L.; Carny, O.; Trudler, D.; Magno, A.; Caflisch, A.; Frenkel, D.; Gazit, E. (2012) Phenylalanine Assembly into Toxic Fibrils Suggests Amyloid Etiology in Phenylketonuria. Nat. Chem. Biol. 8 (8), 701-706.

(10) Reches, M.; Gazit, E. Casting Metal Nanowires Within Discrete Self-Assembled Peptide Nanotubes. Science 2003, 300 (5619), 625-627.

(11) Huang, R.; Su, R.; Qi, W.; Zhao, J.; He, Z. Hierarchical, Interface-Induced SelfAssembly of Diphenylalanine: Formation of Peptide Nanofibers and Microvesicles. Nanotechnology 2011, 22 (24), 245609.

(12) Yan, X.; He, Q.; Wang, K.; Duan, L.; Cui, Y.; Li, J. Transition of Cationic Dipeptide Nanotubes into Vesicles and Oligonucleotide Delivery. Angew. Chem. Int. Ed. 2007, 46 (14), 2431-2434.

(13) Ryu, J.; Kim, S.-W.; Kang, K.; Park, C. B. Synthesis of Diphenylalanine/Cobalt Oxide Hybrid Nanowires and Their Application to Energy Storage. ACS Nano 2010, 4 (1), 159-164.

(14) Dinesh, B.; Basuroy, K.; Shamala, N.; Balaram, P. Structural Characterization of Folded Pentapeptides Containing Centrally Positioned $\beta(\mathrm{R}) \mathrm{Val}, \gamma(\mathrm{R}) \mathrm{Val}$ and $\gamma(\mathrm{S}) \mathrm{Val}$ Residues. Tetrahedron 2012, 68 (23), 4374-4380.

(15) Basuroy, K.; Dinesh, B.; Shamala, N.; Balaram, P. Structural Characterization of Backbone-Expanded Helices in Hybrid Peptides: $(\mathrm{A} \gamma) \mathrm{n}$ and $(\mathrm{A} \beta) \mathrm{n}$ Sequences with Unconstrained $\beta$ and $\gamma$ Homologues of L-Val. Angew. Chem. Int. Ed. 2012, 51 (35), 8736-8739.

(16) Harker, E. A.; Schepartz, A. Cell-Permeable $\beta$-Peptide Inhibitors of P53/HDM2 Complexation. ChemBioChem 2009, 10 (6), 990-993.

(17) Cheloha, R. W.; Maeda, A.; Dean, T.; Gardella, T. J.; Gellman, S. H. Backbone Modification of a Polypeptide Drug Alters Duration of Action in Vivo. Nat.

Biotechnol 2014, 32 (7), 653-655.

(18) Del Borgo, M. P.; Mechler, A. I.; Traore, D.; Forsyth, C.; Wilce, J. A.; Wilce, M. C. J.; Aguilar, M.-I.; Perlmutter, P. Supramolecular Self-Assembly of $N$-Acetyl-

Capped $\beta$-Peptides Leads to Nano- to Macroscale Fiber Formation. Angew. Chem. Int. Ed. 2013, 52 (32), 8266-8270.

(19) Dinesh, B.; Squillaci, M. A.; Ménard-Moyon, C.; Samorì, P.; Bianco, A. SelfAssembly of Diphenylalanine Backbone Homologues and Their Combination with Functionalized Carbon Nanotubes. Nanoscale 2015, 7 (38), 15873-15879.

(20) Lovat, V.; Pantarotto, D.; Lagostena, L.; Cacciari, B.; Grandolfo, M.; Righi, M.; Spalluto, G.; Prato, M.; Ballerini, L. Carbon Nanotube Substrates Boost Neuronal Electrical Signaling. Nano Lett. 2005, 5 (6), 1107-1110.

(21) Cellot, G.; Cilia, E.; Cipollone, S.; Rancic, V.; Sucapane, A.; Giordani, S.; Gambazzi, L.; Markram, H.; Grandolfo, M.; Scaini, D.; et al. Carbon Nanotubes Might Improve Neuronal Performance by Favouring Electrical Shortcuts. Nat. Nanotechnol. 2009, 4 (2), 126-133.

(22) Cellot, G.; Toma, F. M.; Kasap Varley, Z.; Laishram, J.; Villari, A.; Quintana, M.; Cipollone, S.; Prato, M.; Ballerini, L. Carbon Nanotube Scaffolds Tune Synaptic Strength in Cultured Neural Circuits: Novel Frontiers in Nanomaterial-Tissue Interactions. J. Neurosci. 2011, 31 (36), 12945-12953.

(23) Fabbro, A.; Villari, A.; Laishram, J.; Scaini, D.; Toma, F. M.; Turco, A.; Prato, M.; Ballerini, L. Spinal Cord Explants Use Carbon Nanotube Interfaces to Enhance 
Neurite Outgrowth and To Fortify Synaptic Inputs. ACS Nano. 2012, 6 (3), 20412055.

(24) Fabbro, A.; Prato, M.; Ballerini, L. Carbon Nanotubes in Neuroregeneration and Repair. Adv. Drug. Deliv. Rev. 2013, 65 (15), 2034-2044.

(25) Bosi, S.; Rauti, R.; Laishram, J.; Turco, A.; Lonardoni, D.; Nieus, T.; Prato, M.; Scaini, D.; Ballerini, L. From 2D to 3D: Novel Nanostructured Scaffolds to Investigate Signalling in Reconstructed Neuronal Networks. Sci. Rep. 2015, 5, 9562. (26) Usmani, S.; Aurand, E. R.; Medelin, M.; Fabbro, A.; Scaini, D.; Laishram, J.; Rosselli, F. B.; Ansuini, A.; Zoccolan, D.; Scarselli, M.; et al. 3D Meshes of Carbon Nanotubes Guide Functional Reconnection of Segregated Spinal Explants. Sci. Adv. 2016, 2 (7), e1600087.

(27) Aurand, E. R.; Usmani, S.; Medelin, M.; Scaini, D.; Bosi, S.; Rosselli, F. B.; Donato, S.; Tromba, G.; Prato, M.; Ballerini, L. Nanostructures to Engineer 3D Neural-Interfaces: Directing Axonal Navigation toward Successful Bridging of Spinal Segments. Adv. Funct. Mater. 2018, 28 (12), 1700550.

(28) Khan, J.; Das, G.; Gupta, V.; Mohapatra, S.; Ghosh, S.; Ghosh, S. Neurosphere Development from Hippocampal and Cortical Embryonic Mixed Primary Neuron Culture: A Potential Platform for Screening Neurochemical Modulator. ACS Chem. Neurosci. 2018, 9 (11), 2870-2878.

(29) Elsdale, T.; Bard, J. Collagen Substrata for Studies on Cell Behavior. J. Cell Biol. 1972, 54 (3), 626-637.

(30) Smart, A. D.; Course, M. M.; Rawson, J.; Selleck, S.; Van Vactor, D.; Johnson, K. G. Heparan Sulfate Proteoglycan Specificity during Axon Pathway Formation in the Drosophila Embryo. Dev. Neurobiol. 2011, 71 (7), 608-618.

(31) Johansson, F.; Carlberg, P.; Danielsen, N.; Montelius, L.; Kanje, M. Axonal Outgrowth on Nano-Imprinted Patterns. Biomaterials 2006, 27 (8), 1251-1258.

(32) Zhang, J.; Venkataramani, S.; Xu, H.; Song, Y.-K.; Song, H.-K.; Palmore, G. T.

R.; Fallon, J.; Nurmikko, A. V. Combined Topographical and Chemical Micropatterns for Templating Neuronal Networks. Biomaterials 2006, 27 (33), 5734-5739.

(33) Schnaider, L.; Brahmachari, S.; Schmidt, N. W.; Mensa, B.; Shaham-Niv, S.; Bychenko, D.; Adler-Abramovich, L.; Shimon, L. J. W.; Kolusheva, S.; DeGrado, W. F.; et al. Self-Assembling Dipeptide Antibacterial Nanostructures with Membrane Disrupting Activity. Nat. Commun. 2017, 8 (1), 1365.

(34) Galante, M.; Nistri, A.; Ballerini, L. Opposite Changes in Synaptic Activity of Organotypic Rat Spinal Cord Cultures after Chronic Block of AMPA/Kainate or Glycine and GABAA Receptors. J. Physiol. (Lond.) 2000, 523 Pt 3, 639-651.

(35) Turrigiano, G. Homeostatic Synaptic Plasticity: Local and Global Mechanisms for Stabilizing Neuronal Function. Cold Spring Harb. Perspect. Biol. 2012, 4 (1), a005736-a005736.

(36) Scaini, D.; Ballerini, L. Nanomaterials at the Neural Interface. Curr. Opin. Neurobiol. 2018, 50, 50-55.

(37) Mazzatenta, A.; Giugliano, M.; Campidelli, S.; Gambazzi, L.; Businaro, L.; Markram, H.; Prato, M.; Ballerini, L. Interfacing Neurons with Carbon Nanotubes: Electrical Signal Transfer and Synaptic Stimulation in Cultured Brain Circuits. $J$. Neurosci. 2007, 27 (26), 6931-6936.

(38) DeFazio, R. A.; Keros, S.; Quick, M. W.; Hablitz, J. J. Potassium-Coupled Chloride Cotransport Controls Intracellular Chloride in Rat Neocortical Pyramidal Neurons. J. Neurosci. 2000, 20 (21), 8069-8076.

(39) Ostroumov, A.; Simonetti, M.; Nistri, A. Cystic Fibrosis Transmembrane Conductance Regulator Modulates Synaptic Chloride Homeostasis in Motoneurons of the Rat Spinal Cord during Neonatal Development. Dev. Neurobio. 2011, 71 (3), 253268. 
(40) Marconi, E.; Nieus, T.; Maccione, A.; Valente, P.; Simi, A.; Messa, M.; Dante, S.; Baldelli, P.; Berdondini, L.; Benfenati, F. Emergent Functional Properties of Neuronal Networks with Controlled Topology. PLoS ONE 2012, 7 (4), e34648.

(41) Medelin, M.; Rancic, V.; Cellot, G.; Laishram, J.; Veeraraghavan, P.; Rossi, C.; Muzio, L.; Sivilotti, L.; Ballerini, L. Altered Development in GABA Co-Release Shapes Glycinergic Synaptic Currents in Cultured Spinal Slices of the SOD1 G93A Mouse Model of Amyotrophic Lateral Sclerosis: Inhibitory Inputs in the SOD1 ${ }^{\text {G93A }}$ Spinal Cord. J. Physiol. 2016, 594 (13), 3827-3840.

(42) Clements, J. D.; Bekkers, J. M. Detection of Spontaneous Synaptic Events with an Optimally Scaled Template. Biophys. J. 1997, 73 (1), 220-229.

(43) Schindelin, J.; Arganda-Carreras, I.; Frise, E.; Kaynig, V.; Longair, M.; Pietzsch, T.; Preibisch, S.; Rueden, C.; Saalfeld, S.; Schmid, B.; et al. Fiji: (2012) An OpenSource Platform for Biological-Image Analysis. Nat. Methods. 2012, 9 (7), 676-682. 
Table 1. Neuronal passive membrane properties ( $\beta$ peptide substrates)

\begin{tabular}{|c|c|c|}
\hline Substrates & $\begin{array}{c}\text { Membrane } \\
\text { capacitance, } \mathbf{C}_{\mathbf{m}}\end{array}$ & \begin{tabular}{c} 
Input resistance, $\mathbf{R}_{\text {in }}$ \\
\hline$F$
\end{tabular} \\
\hline $\begin{array}{c}\text { poly-ornithine } \\
\mathrm{n}=39\end{array}$ & $37.4 \pm 1.7$ & $1.1 \pm 0.1$ \\
\hline $\begin{array}{c}\beta \text { peptide } \\
\mathrm{n}=58\end{array}$ & $37.7 \pm 1.4$ & $1.3 \pm 0.1$ \\
\hline $\begin{array}{c}\text { CNT- } \beta \text { peptide } \\
\mathrm{n}=51\end{array}$ & $37.8 \pm 1.5$ & $1.1 \pm 0.1$ \\
\hline
\end{tabular}

Table 2. Spontaneous PSCs properties ( $\beta$ peptide substrates)

\begin{tabular}{|c|c|c|c|c|c|c|}
\hline \multirow[t]{2}{*}{ Substrates } & \multicolumn{2}{|c|}{ Spontaneous PSCs } & \multicolumn{2}{|c|}{ Fast PSCs } & \multicolumn{2}{|c|}{ Slow PSCs } \\
\hline & $\begin{array}{c}\text { PSC } \\
\text { frequency }\end{array}$ & $\begin{array}{l}\text { PSC peak } \\
\text { amplitude }\end{array}$ & $\begin{array}{c}\text { PSC } \\
\text { frequency }\end{array}$ & $\begin{array}{l}\text { PSC peak } \\
\text { amplitude }\end{array}$ & $\begin{array}{c}\text { PSC } \\
\text { frequency }\end{array}$ & $\begin{array}{l}\text { PSC peak } \\
\text { amplitude }\end{array}$ \\
\hline & $\mathrm{Hz}$ & $p A$ & $H z$ & $p A$ & $\mathrm{~Hz}$ & $p A$ \\
\hline $\begin{array}{l}\text { Poly-ornithine } \\
n=39\end{array}$ & $2.6 \pm 0.4$ & $47.5 \pm 2.7$ & $1.5 \pm 0.3$ & $41.4 \pm 2.6$ & $1.1 \pm 0.1$ & $70.0 \pm 5.0$ \\
\hline $\begin{array}{l}\beta \text { peptide } \\
n=58\end{array}$ & $1.7 \pm 0.2$ & $47.3 \pm 2.6$ & $0.9 \pm 0.2$ & $41.9 \pm 2.4$ & $0.8 \pm 0.1$ & $68.9 \pm 4.4$ \\
\hline CNT- $\beta$ peptide & $1.2 \pm 0.2$ & $50.8 \pm 2.9$ & $0.8 \pm 0.1$ & $45.5 \pm 2.5$ & $0.5 \pm 0.1$ & $74.8 \pm 5.9$ \\
\hline & $\begin{array}{l}\text { Poly- } \\
\text { ornithine vs. } \\
\beta \text { peptide } \\
P=0.14, \text { vs. } \\
C N T-\beta \\
\text { peptide } \\
P<0.01 \\
\beta \text { peptide vs. } \\
\text { CNT- } \beta \\
\text { peptide } \\
P=0.37\end{array}$ & $\begin{array}{l}\text { Poly- } \\
\text { ornithine } \\
\text { vs. } \beta \\
\text { peptide } \\
P=0.99 \\
\text { vs. CNT- } \beta \\
\text { peptide } \\
P=0.71 ; \\
\beta \text { peptide } \\
\text { vs. CNT- } \beta \\
\text { peptide } \\
P=0.61\end{array}$ & $\begin{array}{l}\text { Poly- } \\
\text { ornithine } \\
\text { vs. } \beta \\
\text { peptide } \\
P=0.43 \text {, } \\
\text { vs. CNT- } \beta \\
\text { peptide } \\
P=0.08 ; \\
\beta \text { peptide } \\
\text { vs. CNT- } \beta \\
\text { peptide } \\
P=0.99\end{array}$ & $\begin{array}{l}\text { Poly- } \\
\text { ornithine } \\
\text { vs. } \beta \\
\text { peptide } \\
P=0.99 \\
\text { vs. CNT- } \beta \\
\text { peptide } \\
P=0.82 ; \\
\beta \text { peptide } \\
\text { vs. CNT- } \beta \\
\text { peptide } \\
P=0.79\end{array}$ & $\begin{array}{l}\text { Poly- } \\
\text { ornithine } \\
\text { vs. } \beta \\
\text { peptide } \\
P=0.17 \text {, } \\
\text { vs. CNT- } \beta \\
\text { peptide } \\
P<0.001 \text {; } \\
\beta \text { peptide } \\
\text { vs. CNT- } \beta \\
\text { peptide } \\
P=0.07\end{array}$ & $\begin{array}{l}\text { Poly- } \\
\text { ornithine } \\
\text { vs. } \beta \\
\text { peptide } \\
P=0.99 \\
\text { vs. CNT- } \beta \\
\text { peptide } \\
P=0.80 ; \\
\beta \text { peptide } \\
\text { vs. CNT- } \beta \\
\text { peptide } \\
P=0.66\end{array}$ \\
\hline
\end{tabular}

Table 3. Calcium imaging recordings ( $\beta$ peptide substrates)

\begin{tabular}{|c|c|c|c|c|}
\hline \multirow[t]{2}{*}{ Substrates } & \multicolumn{2}{|c|}{ Active cells } & \multicolumn{2}{|c|}{ Inter-event interval } \\
\hline & $\begin{array}{c}\text { Spontaneous } \\
\text { activity }\end{array}$ & Bicuculline & $\begin{array}{c}\text { Spontaneous } \\
\text { activity }\end{array}$ & Bicuculline \\
\hline & $\%$ & $\%$ & $\sec$ & $\sec$ \\
\hline $\begin{array}{l}\text { Poly-ornithine } \\
\mathrm{n}=7\end{array}$ & $72 \pm 6.8$ & $84 \pm 6.9$ & $15.2 \pm 1.9$ & $12.0 \pm 1.6$ \\
\hline $\begin{array}{l}\beta \text { peptide } \\
n=6\end{array}$ & $62 \pm 8.9$ & $81 \pm 3.4$ & $18.9 \pm 5.5$ & $8.2 \pm 1.3$ \\
\hline $\begin{array}{l}\text { CNT- } \beta \text { peptide } \\
\mathrm{n}=7\end{array}$ & $65 \pm 11$ & $83 \pm 4.6$ & $17.6 \pm 3.8$ & $11.3 \pm 1.5$ \\
\hline $\begin{array}{l}n=\text { number of } \\
\text { coverslips }\end{array}$ & & & $\begin{array}{l}\text { Poly-ornithine } \\
\text { vs. } \beta \text { peptide } \\
P=0.78 \text {, vs. } \\
\text { CNT- } \beta \text { peptide } \\
P=0.88 ; \\
\beta \text { peptide vs. } \\
\text { CNT- } \beta \text { peptide } \\
P=0.97\end{array}$ & $\begin{array}{l}\text { Poly-ornithine } \\
\text { vs. } \beta \text { peptide } \\
\mathrm{P}=0.20 \text {, vs. } \\
\text { CNT- } \beta \text { peptide } P \\
=0.93 ; \\
\beta \text { peptide vs. } \\
\text { CNT- } \beta \text { peptide } P \\
=0.34\end{array}$ \\
\hline
\end{tabular}


Table 4. Neuronal and glial growth ( $\beta$ peptide substrates)

\begin{tabular}{|c|c|c|c|c|}
\hline \multirow[t]{2}{*}{ Substrates } & \multicolumn{2}{|c|}{ Cell density } & \multicolumn{2}{|c|}{ Fluorescent area } \\
\hline & $\begin{array}{l}\text { Number of } \\
\text { neurons }\end{array}$ & $\begin{array}{l}\text { Number of } \\
\text { astrocytes }\end{array}$ & $\begin{array}{l}\beta \text {-Tubulin III- } \\
\text { positive area }\end{array}$ & $\begin{array}{c}\text { GFAP-positive } \\
\text { area }\end{array}$ \\
\hline & neurons $/ \mathrm{mm}^{2}$ & astrocytes $/ \mathrm{mm}^{2}$ & $\%$ & $\%$ \\
\hline $\begin{array}{l}\text { Poly-ornithine } \\
n=59\end{array}$ & $312 \pm 14$ & $140 \pm 5$ & $26.2 \pm 1.0$ & $22.6 \pm 0.5$ \\
\hline $\begin{array}{l}\beta \text { peptide } \\
\mathrm{n}=70\end{array}$ & $469 \pm 19$ & $151 \pm 5$ & $33.0 \pm 0.7$ & $21.4 \pm 0.5$ \\
\hline $\begin{array}{l}\text { CNT- } \beta \text { peptide } \\
n=52\end{array}$ & $455 \pm 15$ & $170 \pm 4$ & $33.8 \pm 0.8$ & $23.0 \pm 0.5$ \\
\hline $\begin{array}{l}n=\text { number of } \\
\text { fields }\end{array}$ & $\begin{array}{l}\text { Poly-ornithine } \\
\text { vs. } \beta \text { peptide } \\
P<0.001 \text {, vs. } \\
\text { CNT- } \beta \text { peptide } P \\
<0.001 ; \\
\beta \text { peptide vs. } \\
\text { CNT- } \beta \text { peptide } P \\
=0.82\end{array}$ & $\begin{array}{l}\text { Poly-ornithine } \\
\text { vs. } \beta \text { peptide } \\
P=0.30 \text {, vs. } \\
\text { CNT- } \beta \text { peptide } \\
P<0.001 ; \\
\beta \text { peptide vs. } \\
\text { CNT- } \beta \text { peptide } \\
P<0.05\end{array}$ & $\begin{array}{l}\text { Poly-ornithine } \\
\text { vs. } \beta \text { peptide } \\
\mathrm{P}<0.001 \text {, vs. } \\
\text { CNT - } \beta \text { peptide } \\
\mathrm{P}<0.001 \text {; } \\
\beta \text { peptide vs. } \\
\text { CNT - } \beta \text { peptide } \\
\mathrm{P}=0.74\end{array}$ & $\begin{array}{l}\text { Poly-ornithine } \\
\text { vs. } \beta \text { peptide } \\
P=0.30 \text {, vs. } \\
\text { CNT- } \beta \text { peptide } P \\
=0.86 ; \\
\beta \text { peptide vs. } \\
\text { CNT- } \beta \text { peptide } P \\
=0.09\end{array}$ \\
\hline
\end{tabular}

Table 5. Neuronal and glial growth ( $\gamma$ peptide substrates)

\begin{tabular}{|c|c|c|c|c|}
\hline \multirow[t]{2}{*}{ Substrates } & \multicolumn{2}{|c|}{ Cell density } & \multicolumn{2}{|c|}{ Fluorescent area } \\
\hline & $\begin{array}{c}\text { Number of } \\
\text { neurons }\end{array}$ & $\begin{array}{l}\text { Number of } \\
\text { astrocytes }\end{array}$ & $\begin{array}{l}\beta \text {-Tubulin III- } \\
\text { positive area }\end{array}$ & $\begin{array}{c}\text { GFAP-positive } \\
\text { area }\end{array}$ \\
\hline & neuron $/ \mathrm{mm}^{2}$ & astrocytes $/ \mathrm{mm}^{2}$ & $\%$ & $\%$ \\
\hline $\begin{array}{l}\text { Poly-ornithine } \\
n=43\end{array}$ & $161 \pm 10$ & $145 \pm 8$ & $22.6 \pm 1.3$ & $34.6 \pm 1.2$ \\
\hline $\begin{array}{l}\text { Y peptide } \\
\mathrm{n}=46\end{array}$ & $191 \pm 11$ & $160 \pm 8$ & $28.2 \pm 1.6$ & $33.7 \pm 1.5$ \\
\hline $\begin{array}{l}\text { CNT - } \mathrm{y} \text { peptide } \\
\mathrm{n}=47\end{array}$ & $204 \pm 12$ & $180 \pm 10$ & $29.4 \pm 1.9$ & $36.5 \pm 1.5$ \\
\hline $\begin{array}{l}n=\text { number of } \\
\text { fields }\end{array}$ & $\begin{array}{l}\text { Poly-ornithine } \\
\text { vs. Y peptide } \\
\mathrm{P}=0.24 \text {, vs. } \\
\text { CNT-y peptide P } \\
<0.05 ; \\
\text { Y peptide vs. } \\
\text { CNT-y peptide P } \\
=0.99\end{array}$ & $\begin{array}{l}\text { Poly-ornithine } \\
\text { vs. y peptide } \\
\mathrm{P}=0.42 \text {, vs. } \\
\text { CNT-y peptide P } \\
<0.05 \text {; } \\
\text { Y peptide vs. } \\
\text { CNT-y peptide P } \\
=0.22\end{array}$ & $\begin{array}{l}\text { Poly-ornithine } \\
\text { vs. Y peptide } \\
\mathrm{P}=0.05 \text {, vs. } \\
\text { CNT-y peptide P } \\
<0.05 ; \\
\text { Y peptide vs. } \\
\text { CNT-y peptide P } \\
=0.86\end{array}$ & $\begin{array}{l}\text { Poly-ornithine } \\
\text { vs. Y peptide } \\
\mathrm{P}=0.91 \text {, vs. } \\
\text { CNT-y peptide } \mathrm{P} \\
=0.62 ; \\
\text { Y peptide vs. } \\
\text { CNT-y peptide } \mathrm{P} \\
=0.34\end{array}$ \\
\hline
\end{tabular}

Table 6. Neuronal passive membrane properties ( $\gamma$ peptide substrates)

\begin{tabular}{|l|l|c|}
\hline \multicolumn{1}{|c|}{ Substrates } & \multicolumn{1}{|c|}{$\begin{array}{c}\text { Membrane } \\
\text { capacitance, } \mathbf{C}_{\mathbf{m}}\end{array}$} & Input resistance, $\mathbf{R}_{\text {in }}$ \\
\hline \multicolumn{1}{|c|}{$p F$} & $M \Omega$ \\
\hline $\begin{array}{l}\text { Poly-ornithine } \\
\mathrm{n}=29\end{array}$ & $44.9 \pm 2.0$ & $(1.0 \pm 0.1) \times 10^{3}$ \\
\hline $\begin{array}{l}\mathrm{Y} \text { peptide } \\
\mathrm{n}=31\end{array}$ & $39.2 \pm 1.9$ & $(1.2 \pm 0.1) \times 10^{3}$ \\
\hline $\begin{array}{l}\text { CNT- } \mathrm{Y} \text { peptide } \\
\mathrm{n}=34\end{array}$ & $40.7 \pm 2.3$ & $(1.0 \pm 0.1) \times 10^{3}$ \\
\hline
\end{tabular}


Table 7. PSC properties ( $\gamma$ peptide substrates)

\begin{tabular}{|c|c|c|c|c|c|c|}
\hline \multirow{2}{*}{ Substrates } & \multicolumn{2}{|c|}{ Spontaneous PSCs } & \multicolumn{2}{|c|}{ Fast PSCs } & \multicolumn{2}{|c|}{ Slow PSCs } \\
\hline & $\begin{array}{c}\text { PSC } \\
\text { frequency }\end{array}$ & $\begin{array}{l}\text { PSC peak } \\
\text { amplitude }\end{array}$ & $\begin{array}{c}\text { PSC } \\
\text { frequency }\end{array}$ & $\begin{array}{c}\text { PSCs } \\
\text { peak } \\
\text { amplitude }\end{array}$ & $\begin{array}{c}\text { PSC } \\
\text { frequency }\end{array}$ & $\begin{array}{l}\text { PSC peak } \\
\text { amplitude }\end{array}$ \\
\hline & $H z$ & $p A$ & $H z$ & $p A$ & $H z$ & $p A$ \\
\hline $\begin{array}{l}\text { Poly-ornithine } \\
n=29\end{array}$ & $2.6 \pm 0.3$ & $42.0 \pm 2.8$ & $1.8 \pm 0.3$ & $38.6 \pm 2.1$ & $0.9 \pm 0.1$ & $62.5 \pm 8.0$ \\
\hline $\begin{array}{l}\text { Y peptide } \\
n=31\end{array}$ & $2.8 \pm 0.4$ & $45.4 \pm 3.9$ & $2.0 \pm 0.4$ & $45.6 \pm 4.7$ & $0.8 \pm 0.1$ & $66.9 \pm 6.0$ \\
\hline \multirow{2}{*}{$\begin{array}{l}\text { CNT-y peptide } \\
n=34\end{array}$} & $3.7 \pm 0.6$ & $57.5 \pm 5.1$ & $3.0 \pm 0.6$ & $55.3 \pm 5.1$ & $0.7 \pm 0.1$ & $96.5 \pm 13.8$ \\
\hline & $\begin{array}{l}\text { Poly- } \\
\text { ornithine } \\
\text { vs. Y } \\
\text { peptide } \\
\text { P = 0.99, } \\
\text { vs. CNT-y } \\
\text { peptide P } \\
=0.99 ; \\
\text { y peptide } \\
\text { vs. CNT-y } \\
\text { peptide P } \\
=0.99\end{array}$ & $\begin{array}{l}\text { Poly- } \\
\text { ornithine } \\
\text { vs. Y } \\
\text { peptide } \\
P=0.99 \\
\text { vs. CNT-y } \\
\text { peptide } \\
P=0.10 ; \\
\text { y peptide } \\
\text { vs. CNT-y } \\
\text { peptide } \\
P=0.23\end{array}$ & $\begin{array}{l}\text { Poly- } \\
\text { ornithine } \\
\text { vs. Y } \\
\text { peptide } \\
P=0.99 \text {, } \\
\text { vs. CNT-y } \\
\text { peptide } \\
P=0.99 \\
\text { Y peptide } \\
\text { vs. CNT-y } \\
\text { peptide } \\
P=0.99\end{array}$ & $\begin{array}{l}\text { Poly- } \\
\text { ornithine } \\
\text { vs. Y } \\
\text { peptide } \\
P=0.99 \\
\text { vs. CNT-y } \\
\text { peptide } \\
P=0.07 \\
\text { y peptide } \\
\text { vs. CNT-y } \\
\text { peptide } \\
P=0.15\end{array}$ & $\begin{array}{l}\text { Poly- } \\
\text { ornithine } \\
\text { vs. Y } \\
\text { peptide } \\
P=0.99 \\
\text { vs. CNT-y } \\
\text { peptide } \\
P=0.99 \\
\text { Y peptide } \\
\text { vs. CNT-y } \\
\text { peptide } \\
P=0.99\end{array}$ & $\begin{array}{l}\text { Poly- } \\
\text { ornithine } \\
\text { vs. Y } \\
\text { peptide } \\
\text { P = 0.87, } \\
\text { vs. CNT-y } \\
\text { peptide P } \\
=0.08 ; \\
\text { y peptide } \\
\text { vs. CNT-y } \\
\text { peptide P } \\
=0.73\end{array}$ \\
\hline
\end{tabular}


<smiles>CC(C)(C)OC(=O)NC(CC(=O)NC(CC(=O)O)Cc1ccccc1)Cc1ccccc1</smiles>

Boc- $\beta^{3}(\mathrm{R}) \mathrm{Phe}-\beta^{3}(\mathrm{R}) \mathrm{Phe}-\mathrm{OH}$ $\beta$ peptide<smiles>CC(C)(C)OC(=O)NC(CCC(=O)NCCC(Cc1ccccc1)C(=O)O)Cc1ccccc1</smiles>

Boc- $\gamma^{4}(\mathrm{R}) \mathrm{Phe}-\gamma^{4}(\mathrm{R}) \mathrm{Phe}-\mathrm{OH}$ $\gamma$ peptide

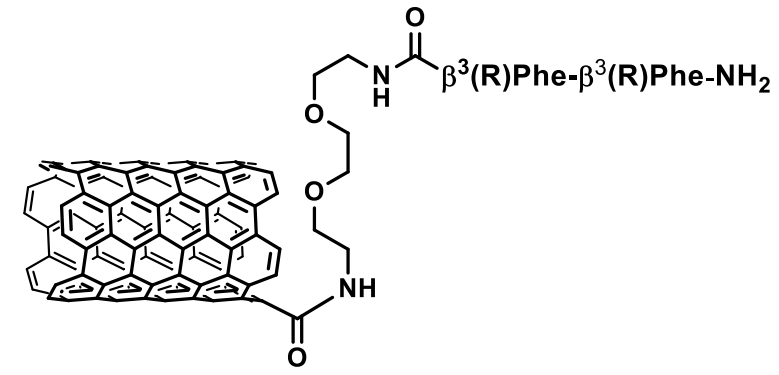

CNT $\beta$ peptide

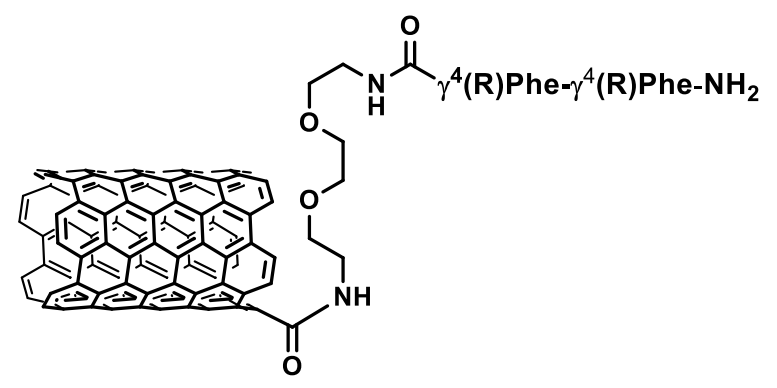

CNT $\gamma$ peptide

\section{Figure 1.}

Molecular structures of the $\beta$ and $\gamma$ peptides (top line and bottom line, respectively) and the corresponding CNT-peptide conjugates (on the right). 
(a)
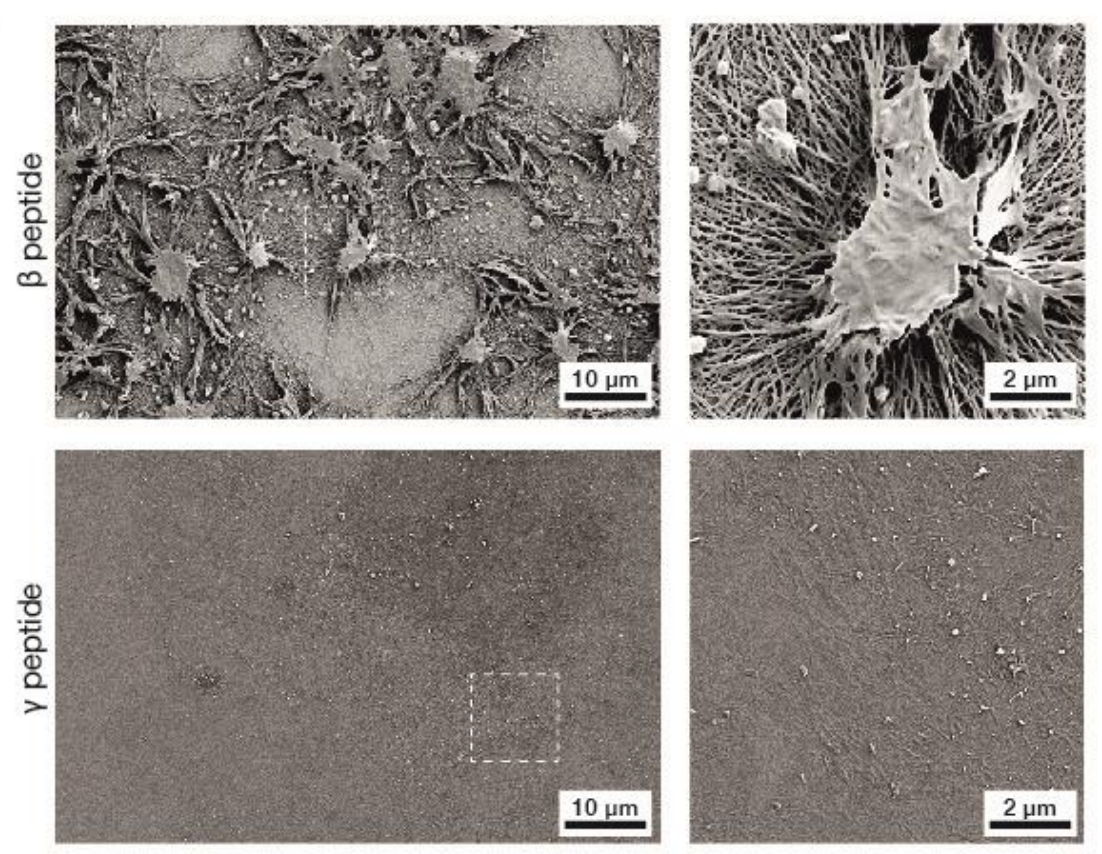

(b)
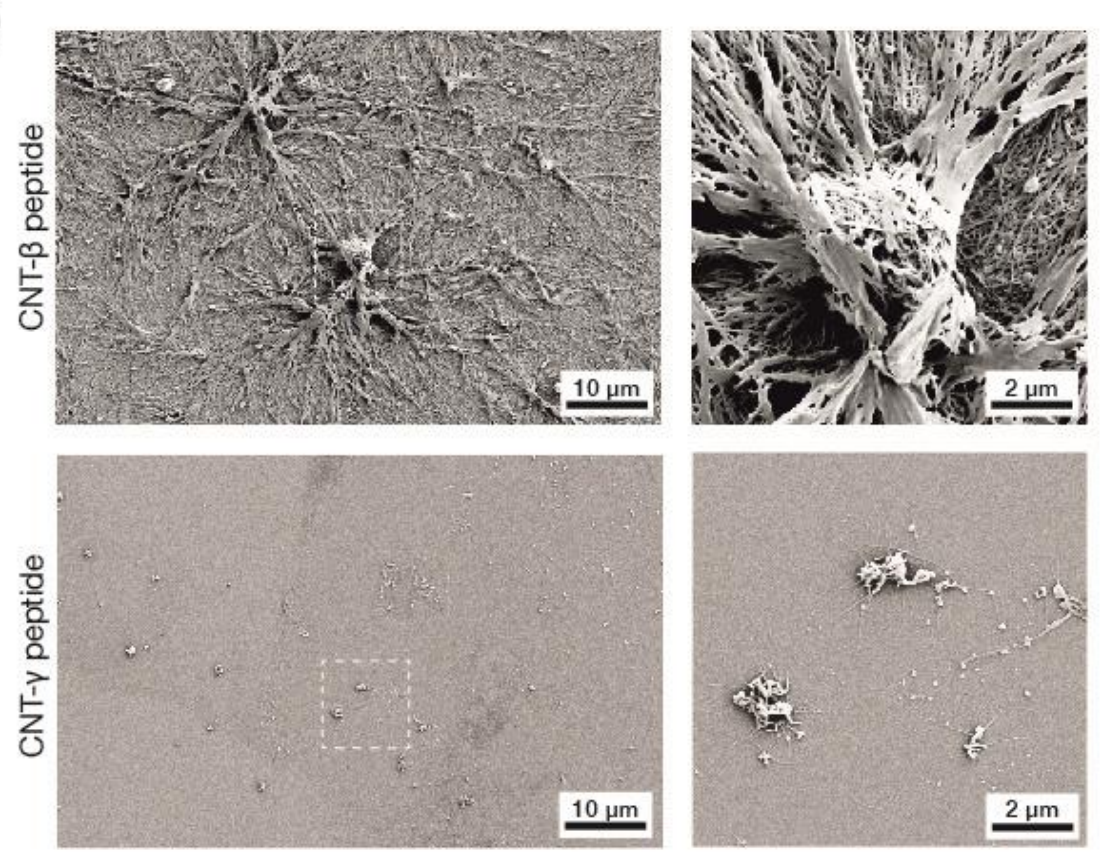

\section{Figure 2.}

SEM images of the $\beta$ and $\gamma$ peptide (a) and the CNT- $\beta$ and CNT- $\gamma$ peptide (b) at different magnifications. 
(a)

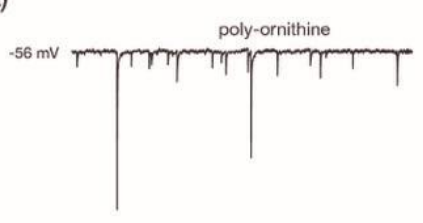

(b)

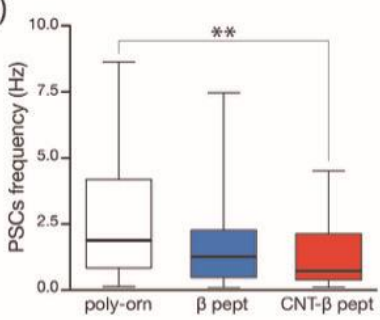

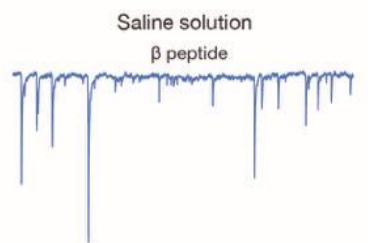
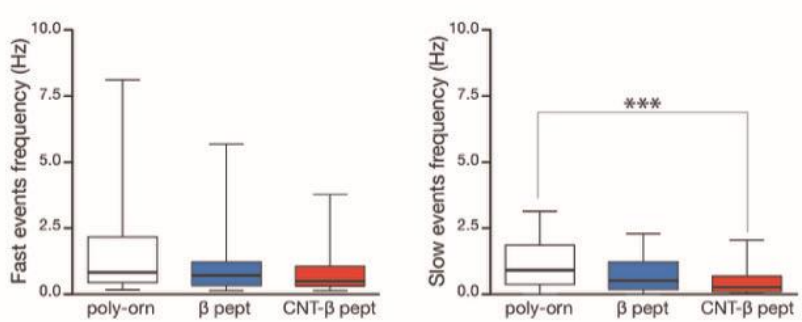

(d)

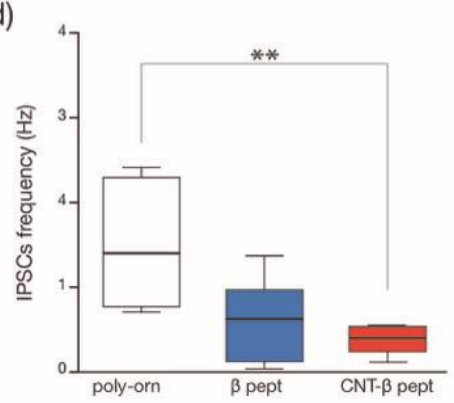

\section{Figure 3.}

(a) Representative traces of spontaneous PSCs recorded from neurons grown on polyornithine, $\beta$ peptide and CNT- $\beta$ peptide in standard saline solution. Holding potential $=$ $-56 \mathrm{mV}$ (b) Box plots summarize PSCs frequency values calculated for total spontaneous PSCs (left), only fast events (middle) and only slow events (right). Polyornithine is represented in black, $\beta$ peptide in blue and CNT- $\beta$ peptide in red. Note the progressive decrease in PSCs frequency from poly-ornithine to CNT- $\beta$ peptide. (c) Example of pharmacologically isolated IPSCs showing a decrease in their frequency when neurons are grown on CNT- $\beta$ peptide as reported in the box plots of their average frequencies in (d). 
(a)

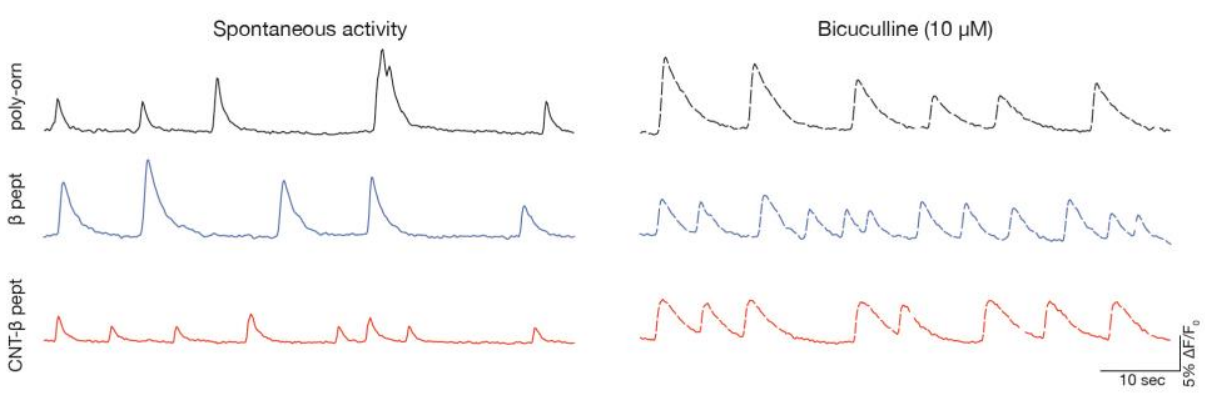

(b)

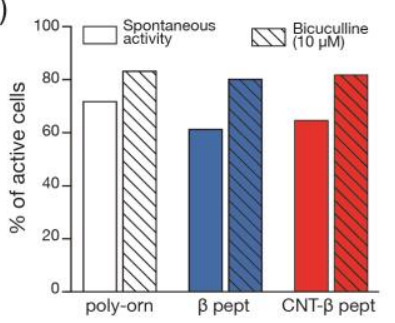

(c)

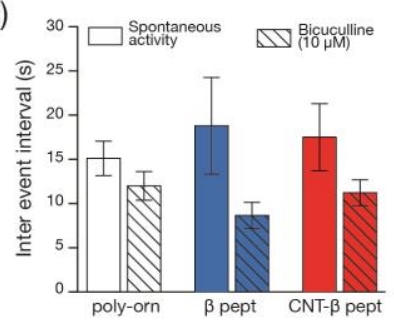

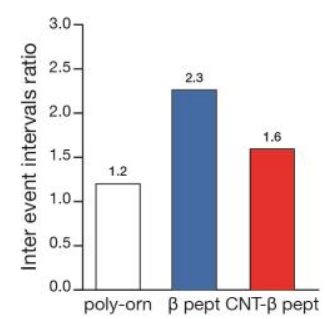

\section{Figure 4.}

(a) Repetitive $\mathrm{Ca}^{2+}$ events spontaneously (left) or bicuculline-induced (right) recorded from hippocampal neurons grown on control and nanomaterials. Histograms summarize the percentage of active cells (b) and the average values of IEI (c, left) in spontaneous activity (plain colors) and bicuculline condition (striped) for the three different conditions. The ratio between inter event intervals of spontaneous and bicuculline induced events is represented in (c, right). 
(a) DAPI / B-Tubulin III
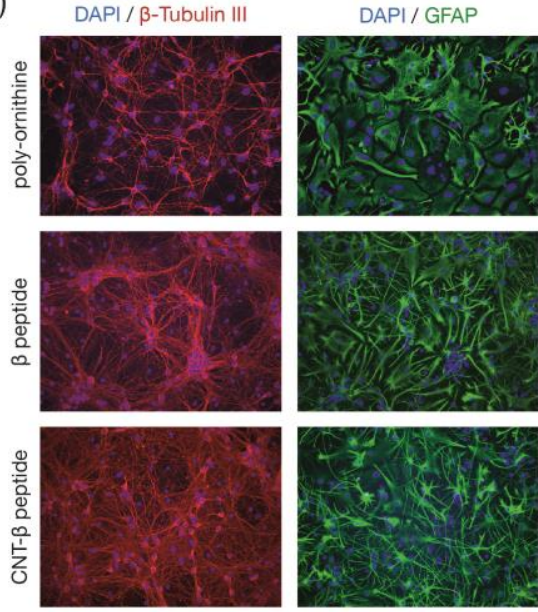

(c)

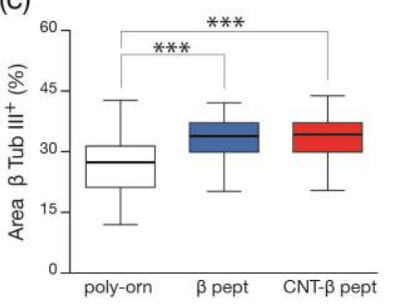

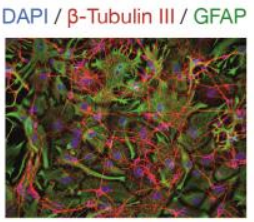
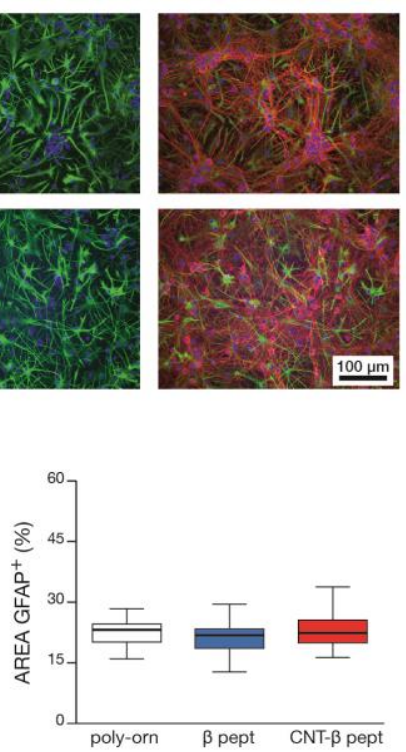
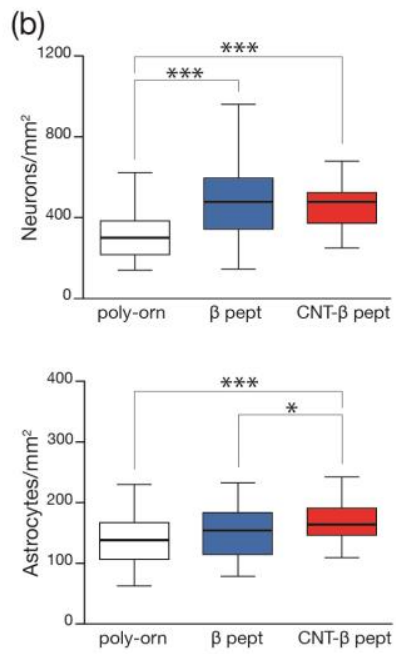

(d)

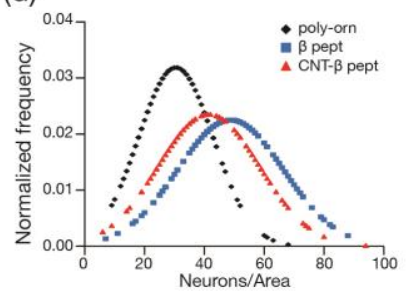

\section{Figure 5.}

(a) Immunofluorescence images of hippocampal cultures grown on poly-ornithine (top), $\beta$ peptide (middle) and CNT- $\beta$ peptide (bottom), labeled for the glial GFAP (in green), the neuronal $\beta$-tubulin III (in red) and the nuclei DAPI (in blue) markers. Histograms in (b) summarize the number of neurons (top) and astrocytes (bottom) while in (c) the percentage of $\beta$-tubulin III-positive area (left) and GFAP-positive area (right) calculated on the three different substrates are shown. (d) Gaussian curves representing the neuronal density distribution measured on poly-ornithine (black), $\beta$ peptide (blue) and CNT- $\beta$ peptide (red). Note the different network geometry of neurons grown on the nanomaterials compared to the control condition. 
(a)

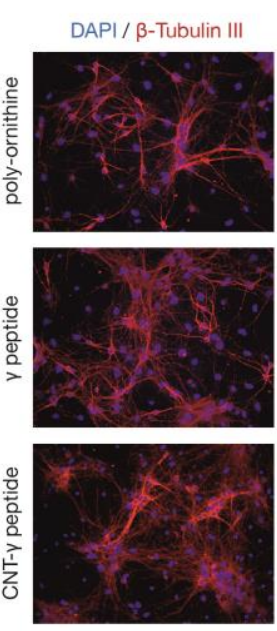

(c)

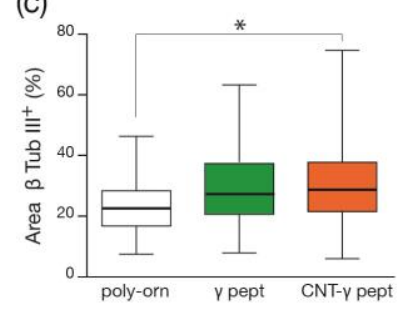

DAPI / GFAP
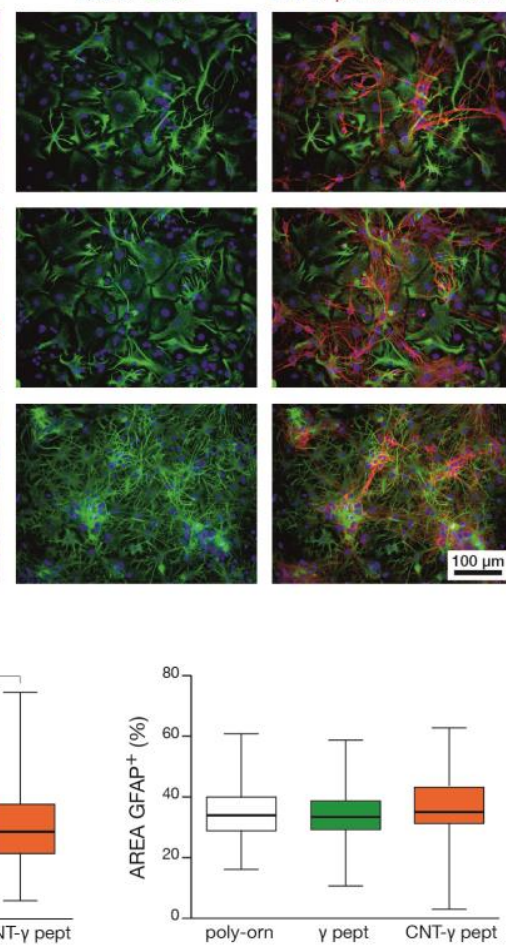

(b)
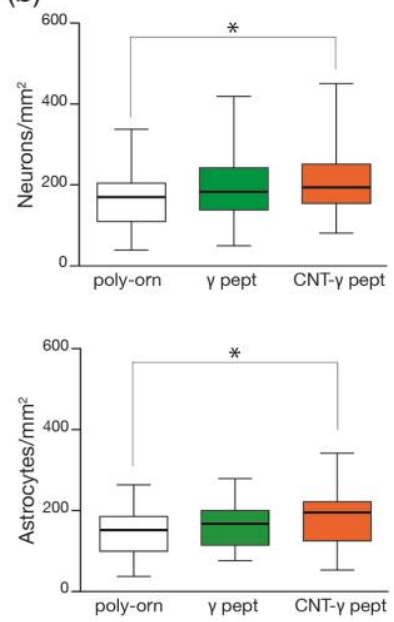

(d)

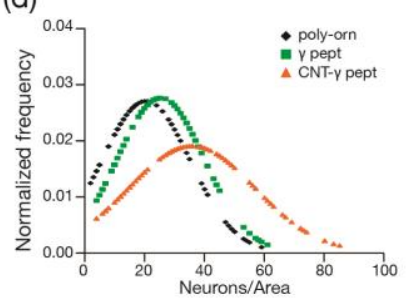

\section{Figure 6.}

(a) Immunofluorescence images of hippocampal cultures grown on poly-ornithine (top), $\gamma$ peptide (middle) and CNT- $\gamma$ peptide (bottom), labeled for the glial GFAP (in green), the neuronal $\beta$-tubulin III (in red) and the nuclei DAPI (in blue) markers. Box plots and histograms in (b) summarize the number of neurons (top) and astrocytes (bottom) while in (c) the percentage of $\beta$-tubulin III-positive area (left) and GFAPpositive area (right) calculated on the three different substrates are shown. In (d) Gaussian curves representing the neuronal density distribution measured on polyornithine (black), $\gamma$ peptide (green) and CNT- $\gamma$ peptide (orange). 
(a)

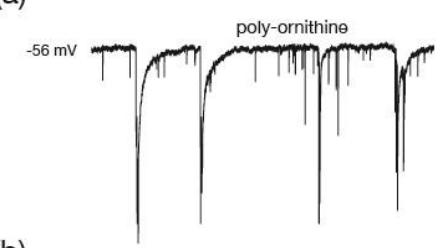

(b)

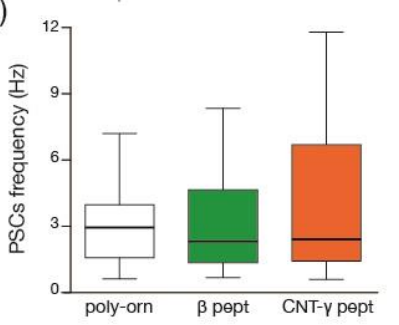

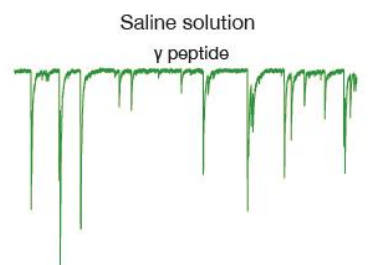

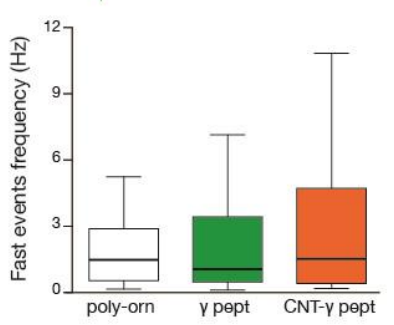

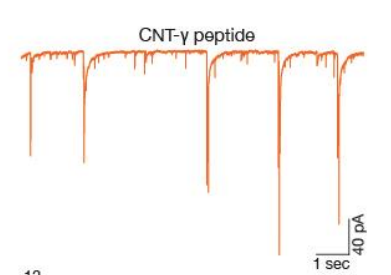

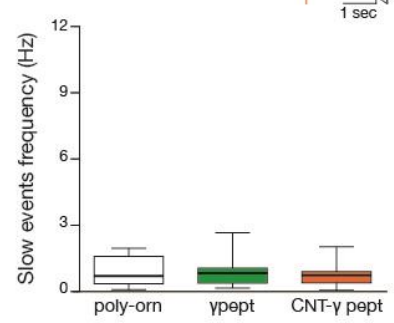

\section{Figure 7.}

(a) Representative traces of spontaneous PSCs recorded from neurons grown on polyornithine, $\gamma$ peptide and CNT- $\gamma$ peptide. Holding potential $=-56 \mathrm{mV}$. In (b) box plots summarize PSCs frequency values calculated for total spontaneous PSCs (left), fast events (middle) and slow events (right). Poly-ornithine is represented in black, $\gamma$ peptide in green and CNT- $\gamma$ peptide in orange. 